In 7 India $\quad$ The French Journal of Media Studies

8.1. $\mid 2020$

Ubiquitous Visuality

\title{
Selfies, Digital Self-Portraits, and the Politicization of Intimacy
}

Juliette Melia

\section{Q OpenEdition \\ 1 Journals}

\section{Electronic version}

URL: http://journals.openedition.org/inmedia/2156

DOI: 10.4000/inmedia.2156

ISSN: 2259-4728

\section{Publisher}

Center for Research on the English-Speaking World (CREW)

\section{Electronic reference}

Juliette Melia, "Selfies, Digital Self-Portraits, and the Politicization of Intimacy", InMedia [Online], 8.1. I 2020, Online since 15 December 2020, connection on 26 January 2021. URL: http://

journals.openedition.org/inmedia/2156 ; DOl: https://doi.org/10.4000/inmedia.2156

This text was automatically generated on 26 January 2021.

(c) InMedia 


\title{
Selfies, Digital Self-Portraits, and the Politicization of Intimacy
}

\author{
Juliette Melia
}

\section{Introduction: From Self-Portrait to Selfie and Back Again}

1 I remember a TV ad for one of the first digital cameras. The ad was extremely fastpaced and staged numerous ways of shooting photographs to show that this new technology actually revolutionized photography. One scene stuck with me, probably because it seems to illustrate an impulse for self-representation: a young man was shooting a flash photograph inside his tee-shirt, then looked up at his control screen, surprised as much by the unprecedented result as by the freedom and spontaneity that would have been hampered by some aspects of analogue photography, be it only the price of the processing. ${ }^{1}$

Gisèle Freund, in Photographie et Société, argues that this need for self-representation, which can superficially appear trivial, is in fact a political act. It intensified at the dawn of the industrial revolution, when larger segments of the middle-classes started accessing positions of wealth and power and consequently became more and more able to afford and commission portraits of themselves. This was symbolic of aristocracy's loss of influence and privilege. ${ }^{2}$ This begs the question of whether or not this politicization persists nowadays with the acceleration of photo-taking and the trend of turning the camera on oneself.

In the early 2000s, the term selfie was coined for digital, networked self-portraits, following key technological advances: the democratization of smartphones in South East Asia, Europe and the US; the improvement of the quality of their integrated cameras; and most importantly the introduction of high resolution front-facing cameras on iPhones. It is now a well-known fact that selfie became Oxford Dictionary word of the year in 2013. What matters is that, according to Google trends, after definite peaks in 2013 and 2016, the word is still in large circulation today, as opposed 
to other words of the year such as chav (2004), hypermiling (2008), and youthquake (2012), the use of which has thoroughly dwindled.

4 Selfies have become the subject of much journalistic and scholarly discourse, taking centre stage in discussions about new modes of representations of the self. Visual culture theorist Nicholas Mirzoeff insightfully highlighted the new role of selfies in social interaction and belonging: "[d]espite the name, the selfie is really about social groups and communications within those groups." ${ }^{3}$ The visual and textual (through comments, likes, and further sharing) conversations allowed by selfies are one of their defining aspects. Nevertheless, the media periodically gives credence to a sort of moral panic over selfies and selfists, supposedly selfish, self-absorbed and narcissistic. ${ }^{4}$ Ten years on, the selfie-inspired conversations run strong and scholarly discourse still finds aspects of the selfie to analyse. ${ }^{5}$

5 According to the aforementioned Oxford definition, a selfie should respect (at least) three criteria: the self-portrait element-it has to be an image of oneself-the technological element-it must be taken with the camera of one's smartphone or webcam-and the networking element-if the selfie is not shared on social media, in a way that allows comments, likes and further sharing, it cannot be considered a fullblown selfie. Some elements of this definition are debatable: aren't there, on computers and smartphones, selfies that will never be shared? Without the shadow of a doubt, there are, but my point is that a selfie that does not place itself in the public sphere of social media, allowing comments, likes, shares and potential further manipulations, is not completely a selfie.

6 The preconception about a photographic self-portrait is that it is often carefully set up, sometimes even with a tripod and a timer or cable-release. Contrastingly, a selfie is supposed to have an aesthetic that indicates its spontaneity: most of them are shot at arm's length, with the lens slightly above the eyes to make them look bigger and minimize the size of the chin and cheeks. Additionally, social media platforms that specialize in the sharing of photographs, both Instagram and Flickr, offer ready-made filters $^{6}$ that make each image more striking thanks to added contrast or photographic effects like vignetting, for example. Cumulatively, that is to say if everybody uses the same popular filter, the production becomes standardized.

In addition to its dictionary definition and its idiosyncratic aesthetics, there are two intertwined conceptions of the selfie. On the one hand, it is a production of little worth, the epitome of the disposable image described by Hito Steyerl as "the debris of audiovisual production, the trash that washes up on the digital economies' shores." On the other hand, it is a symptom of the sea change that new technologies have brought to society, questioning our relationship to our identity and the possibility of it being shared, thus altering our public and private behaviours. I would like to add to this conversation the question of how the selfie contributes to the articulation and publicization of our personal politics in a way that we can describe as infra-political, as articulated by James C. Scott's theory of domination and resistance. ${ }^{8}$ The field of infrapolitical art is at the limit between apolitical and political art, because it "encompasses the acts, gestures and thought that are not quite political enough to be considered as such." $\mathrm{A}$ degree of subjective appreciation of whether a work qualifies as political is thus one of the hurdles of the present reflexion, as well as the fact that the works, being made by subaltern populations, might go unnoticed. When photographers use the blend of visibility and anonymity allowed by social networks to undermine real 
or perceived oppression, when they perform or redefine the self through the selfie, in what ways can they be considered as infrapolitical?

In what follows, I propose to take the focus of my discussion away from the images that correspond strictly to the initial three-pronged definition (self-portrait, smartphone, social media), because it would automatically disqualify a worthy corpus of quasiselfies, self-portraits that are shot with a digital camera, or even an analogue camera, then scanned. Indeed, my point is that the salient aspect of the selfie is that it is shared online with strangers who can comment on it; it is a "networked image," ${ }^{10}$ as Rubinstein and sluis described the emerging corpus of shared digital snapshots that accompanied the democratization of digital cameras, then of smartphones. It is this networked aspect that gives selfies and self-portraits their political importance, because they make the intimacy of the user public (more so, for example, than a street scene or a still life, because in those genres of photography the user's appearance is not at stake). The technical aspect, that is to say the device they were shot with, is in my opinion of lesser importance. What matters is how the networked self-portraits disrupt the politics of representation by introducing the amateur artist's personal set of values governed by their own (infra-)politics in the public arena that is the Internet.

\section{Corpus: Flickr, "of me" Albums and "365days" Groups}

9 My corpus will be composed of photographs uploaded to the North American photosharing website Flickr (2004). Although it has users worldwide, I will focus my analyses primarily on content uploaded by English-speaking (mainly American) users. Some of the remarkable features of Flickr are that it allows the downloading and filing of 1000 photos for free and an unlimited amount of photos for $\$ 60$ a year. The filing component of Flickr is a throwback to analogue photography, when people used to sort their photographs in thematic or chronological albums. It is also a useful aspect of the website for research about self representation. When albums were clearly titled "Selfportraits," "Selfies," or "Me" for example, they signalled that their content would be relevant for my analyses. The presence of albums also allows a longer shelf-life, so to speak, for the photographs. Indeed, an older photograph can be more easily accessed if the photographer puts it in an album that is at the top of their photostream, instead of being effectively buried beneath all the newer photographs, as can be the case on Instagram, for example.

10 To compare, again, Flickr with the newer and more popular Instagram, the latter is geared toward smartphone users, whereas photographs on Flickr are not only taken with smartphones, but also, for a lot of them, with cameras, sometimes even professional ones, as shown in the breakdown of cameras used available on the site. ${ }^{11}$ In addition to being a place to store photographs, Flickr also claims to be a community, with its many thematic groups that all have their own forum. Among these groups, some are dedicated to self-portraits and selfies. One trend, started by Flickr user Chris Maverick in 2004 called "365days," called participants to shoot one self-portrait everyday for a year and post it daily to the pool of photographs. In 2014, a large-scale study on selfies was carried out by media researchers and published on the website Selfiecity. ${ }^{12}$ One of the results was that selfists were predominantly young and female. It appears at a glance that, maybe because Flickr is an older site than Instagram, the photographers taking part in the 365 days challenge are more diverse than the initial 
Selfiecity findings: they are older and equally male and female. ${ }^{13}$ Consequently, the pool will probably demonstrate more diversity in the moods and themes represented.

These Flickr albums and photographic pools provide a new outlook to consider whether people represent themselves for political reasons. Some of these amateur photographers have very humble approaches to themselves and their daily selfportraits, they want to document one noteworthy (for them) aspect of their day, with neither apparent artistic intention nor political commitment in their contents, their staging or their metatextual elements. But others, and they are the ones who will be part of my corpus, use selfies and self-portraits as a new mode of identity performance, a way to show the world, via the web, that they are the only expert on themselves, and as such, are the only one who can truly represent themselves..$^{14}$ Through the case study of selfies and self-portraits found on the Flickr albums dedicated by their authors to self representation, I will shine a light on what the resulting production achieves, both artistically and politically. Can a self-portrait or a selfie be both intimate and politically engaged? In what measure does sharing intimate and potentially subversive images of oneself on a public platform contribute to altering the conversations about otherness?

\section{Narcissism: The Gaze in a Closed Loop}

Posting self-portraits online on a regular basis, as the participants in the 365days group do, might be considered as a sort of self-imposed incarceration in a digital panopticon. The panopticon was a prison system invented by English philosopher Jeremy Bentham in 1791 (but never built), in which the inmates can be watched all the time by somebody they cannot see. The point of the panopticon is the power of the gaze to control the unruly body. In the panopticon, the prisoners are supposed "to discipline themselves, that is to say, to subject themselves to a series of norms." ${ }^{15}$ This might explain the popular preconception that some selfies are standardized, the genre of the duckface being a commonly derided symbol thereof. Feeling disempowered by an increasingly dehumanizing society, the selfist tries to regain control over their own image through acceptance by a group, instead of the adoption of a political, potentially controversial stance. This means staging the selfie to conform to the genre, tagging it appropriately (or ironically), and posting it online for at least one viewer to see and evaluate its conformity to the norm. The photostream becomes a digital panopticon, perceived by its detractors as disempowering rather than empowering.

Another disempowering aspect of the recurrent posting of selfies and self-portraits online would be a sign of supposed narcissism. As noted by Professor Paul Frosh in his article "The Gestural Image: The Selfie, Photography Theory, and Kinesthetic Sociability,"16 selfies are supposed to be narcissistic: "the accusation of narcissism is one of the most common themes in public discourse about selfies." Writer and ethnographer Anne Burns however helps overturn the cliché of the selfist as necessarily selfish and narcissistic. She argues that criticising the selfie as a practice is "a means for enacting discipline and social control [and] seek[s] to regulate subjects as they enter the public sphere of the Internet, prescribing how visible, on what terms, and with what characteristics, such subjects can be made or permitted to appear. ${ }^{17}$ For Burns, even the most stereotypical selfie is a worthy speech act, and any attempt at censoring it or belittling it through contempt paradoxically emphasizes its political scope. 
14 Even if we go back to the origins of the term with Ovid's myth of Narcissus, who fell in love with his own reflection and died as a result, the myth hardly matches the ethos of contemporary selfists, who are neither in love with nor particularly aroused by their own image. It is thus a methodological shortcut to equate online self-portraits and narcissism. Rather, photographers use their own image to try and start a conversation with others. This seems to contradict the accusations not only of self-absorption and selfishness, but also of unhealthy performance of the self when an unreal, monitored, artificially positive identity is created. Indeed, if the image presented is too far removed from the person represented, the conversations it might trigger are bound to be unsatisfactory. This is why the photographers I will study tend to share their vulnerabilities more than their strengths, as we shall see in the case studies. Posting any image is the acceptance to relinquish control over it, but more blatantly so when the image is a self-portrait. The photographer hence risks negative comments about oneself and one's appearance. Most selfies do not seek to seduce through the glorification of their author's personality. On the contrary, their force is their awareness of the little importance they have and the consequent multiplication of the occurrences. Indeed, seriality is one of the tropes of selfie-taking, as is shown in the numerous Flickr albums dedicated to the genre, as well all the groups for serial selfportraits: 365days, 365more, 365daysAlumni, 52weeks, etc.

Even though selfie-taking is not an inherently narcissistic practice, Bertrand Naivin seems to have found one possible characteristic of selfies that can be considered as a manifestation of its practitioner's narcissism. He calls it "le regard-de-biais du selfiste," 18 that is to say, the photographers are not confronting their viewers through the camera lens, but rather looking at themselves in their smartphone screen instead of looking into the lens of the camera, or looking away altogether. That way, the control of the image is absolute: there is no letting go, no poetic or creative uncertainty as to what the selfie is going to look like. As an example (outside our corpus), the celebrity associated with that kind of selfie is Kim Kardashian, whose mirror selfies often represent her looking at herself looking at herself, her gaze seemingly caught in a closed loop.

Closed loop selfies are not common among the selfies of Flickr, maybe because it is an older website, or maybe because it has a reputation of more, if not professional, still serious photography. When the gaze is actually skewed toward the photographers photographing themselves, there is often an element of metaphotographic insistence on this choice of staging. One example is Lizzie's self-portrait in a mirror, shot with a small bridge camera: its colloquial title and rounded fingers ironically highlight the offending eye in "Ghetto mirror selfie?" ${ }^{19}$ We also notice that the eye is the exact same dark-blue colour as the ring of the camera lens, creating a cyborg effect, as if the camera was an extension of the young woman's body. This occurrence initially reads as more humorous than highly committed or political. Still, there is an element of subversion in it. Indeed, this photographer represents herself knowing that the staging she has chosen can potentially be criticized, through the reappropriation of the negative word "ghetto" and the question mark that seems to challenge the viewer. Even if this selfie does not achieve any political feat, it demonstrates a defiant state of mind that may prove useful for more relevant political struggles. 


\section{Intimacy and Gender In-Betweenness: Ray Bernoff}

The series of digital self-portraits made by the Flickr user Ray Bernoff is an example of the depth into intimacy that can be shared online with potential strangers. In the continuum from high-art, painterly self-portrait tradition, to the disposable, spontaneous, in a word vernacular selfie, Ray Bernoff's approach leans slightly toward the former, in part because of his use of high quality digital cameras. But I would contend once again that the technological aspect of the self-portrait/selfie is of lesser importance: what matters for my point is the leap of faith one makes when one uploads a photograph of oneself to the public space that is a social network: if a photographer has a political message, to what extent will it be perceived, then understood as its author expected it to be?

Besides, one could argue that as a professional photographer, Bernoff displaces the convention of the selfie as a purely amateur practice, but it seems that his self-portrait work is personal work and not professional. As I have begun to establish in my introduction, if a conventional selfie is taken at arm's length with a smartphone, possibly edited or enhanced with ready-made filters, and instantly uploaded on a photographic platform, Bernoff's representations of himself are more self-portraits than selfies, mainly because they are shot with a professional Nikon camera and not the camera of his phone, creating, to quote Steyerl, "a high-resolution image [that] looks more brilliant and impressive, more mimetic and magic, more scary and seductive than a poor one." ${ }^{20}$ Here again, the corpus is in a liminal space, between the worthless and the valued. In Bernoff's case, we are allowed to take part in a journey of gender reassignment surgery. This process starts (for us viewers) in 2011 with a young girl shooting a selfie in public toilets with a Sony compact camera ${ }^{21}$ and is ongoing now that Ray is an older, bearded man. ${ }^{22}$

19 Some self-portraits stand out in his work: those in which he rejects both male and female stereotypes. In glitter, ${ }^{23}$ for example, the male face is feminized by sparkly, glittering make-up around the eyes and on the lips, its shiny textures contrasting with the dark stubble on the artist's jaw. Bernoff chooses to refuse the strict male or female label society assigns anyone. He places himself firmly outside the norm, not only by documenting the intimate surgical process of gender reassignment that is generally considered private, but also by tailor-making a representation of his own non-binarity, rejecting the perceived oppression of a binary gender and introducing some fluidity in the politics of representation of transmasculinity.

20 Making his intimacy public in that way (one of his albums, entitled "Intimacy," is composed not only of selfies and self-portraits, but also of various images of his bedroom, his friends, his hormonal treatment, etc.) is the political raison d'être of his approach, and probably also the reason for my interest in him. According to French art historian Elisabeth Lebovici, intimacy is an undervalued notion in this patriarchal society, because it is associated to femininity. ${ }^{24}$ But this is precisely the reason why it is necessary for Bernoff, who stands at the crossroads between femininity and masculinity in some of his self-portraits, to perform and redefine his intimacy. As argued for a long time by feminists since the success of Carol Hanisch's seminal text "The Personal is Political" ${ }^{25}$, the use of personal, or in other words intimate, aspects of the artist's life, can give more depth to the political meaning of the work. 
21 Bernoff wishes for more visibility, on his own terms, and takes the initiative of his representation, which in turn allows him to express fully his subjectivity. This selfexpression is entirely devoid of any feelings of shame or guilt. On the contrary, he uses the subjective narration of his intimacy allowed by the representation of the self online to give a personal representation of his transsexuality. His self-portraits are so humble that they might fall under the radar, thus losing some of their potential political scope. Indeed, glitter numbers slightly less than 500 views in 2020 after five years online, and it can be argued that selfies have more political efficiency when they are more widely seen. Still, they are out there for the world to see, and reinvent the artist's self to fight the oppression of heterosexual normativity. This discourse can be qualified as infrapolitical ${ }^{26}$ in an American society that is still characterized by hostility and violence towards its transgender and gender non-conforming communities, as shown, to quote but two examples, by bathroom bills such as the Public Facilities Privacy \& Security Act approved as law in North Carolina in 2016, a piece of legislation that aims to regulate access to public toilets depending on the sex people are assigned at birth and, even more worryingly, by the disproportionate number of violent deaths of transgender people (more than thirty-three in 2020 according to the Human Rights Campaign data collection). ${ }^{27}$

\section{Bad Day and Catharsis: Nicole Reber}

The archival element ${ }^{28}$ intrinsic to the Internet makes it possible to trace the probable first photograph that used the term selfie in its caption: in 2002, an Australian student, using the screen name Hopey, photographed a wound on his lips to ask advice about how to care for it, thus creating the seminal selfie. ${ }^{29}$ Indeed, not only does it correspond to its definition, a photograph taken of oneself with a smartphone and uploaded online, but it also makes its common use clearer: it asks others to validate a state of being. ${ }^{30}$ Maybe this is the reason why the term selfie gained such traction, a new word for a new way of communicating with others, to generate conversations about oneself in order to know oneself better through the responses. Yet, in what measure can this validation through peers and strangers be political, and not merely self-indulgent?

Flickr user Nicole Reber (Oklahoma City, active from 2008 to 2015), articulated this need for validation in her album entitled "Emotions," ${ }^{31}$ in which she lays bare the aspects of her intimacy that are her health problems, namely chronic pain and anxiety, through images of herself. She calls these images self-portraits (the term selfie does not appear in the breakdown of her tag use, ${ }^{32}$ even after the early 2010s when the term started trending). Although she is an amateur photographer, she offers her prints for sale. She typically uses a camera to shoot her self-portraits, and very seldom a smartphone. For all these reasons, and like most of the photographers discussed in this text, she does not correspond to the definition of the selfist, who shoots only with his or her smartphone. Rather, she exemplifies a use of self-representation that draws on personal issues to generate conversations that may have therapeutic or comforting effects. Her photograph entitled "Day 33: Do you ever feel like crying?" ${ }^{33}$ shows a closeup of her face, her eyelashes matted, her cheeks bathed in tears. The subtitles: "Do you ever feel like giving up? Bad day." are even more ominous and make the viewer of this photograph wonder if it is a potential suicide note. The following twenty or so comments are all comforting, offering actual or virtual support, so Reber's likely initial 
purpose in posting this cry for help might have been met, her self-portrait has generated a conversation about herself on her own terms. It remains for us to wonder why this-hopefully-ephemeral mood is still archived online well after the tears have dried. Can this photograph have a value beyond the conversational? In a minute and mundane way, its political value is reinforced by its archiving, because it remains available for future study, case in point being the present article.

Hannah Arendt, in Condition de l'Homme moderne,$^{34}$ separates the private and the public spheres, and defines privacy as essentially opposed to society. This creates a productive paradox on art and intimacy, because the consequence of using your intimacy in your art is the destruction of said intimacy. My point is that such a sacrifice has a purpose, that of creating a cathartic identification between photographer and viewer. Beyond the validation of a state of being or of a state of mind, the politics of the self-portrait is also to share an intimate image of oneself as a link toward its viewers, who can potentially recognize their own state of being or state of mind in the work and, in turn, use it to support and comfort themselves.

For that kind of work, historian and art critic Dominique Baqué uses the term "subpolitics" 35 as a way to disqualify any political interpretation of art that uses intimacy. Baqué means that, being too focused on the artist as a person, intimate art cannot reach its full political potential, because it is too self-centered. For Baqué, political art cannot be focused on its creator but must look out upon the outside world. I want to contend that selfies and self-portraits can be political precisely because they do not claim to be, but unwittingly show the reflexion of the outside world on the photographers' faces. Throughout Reber's “Emotion" Flickr photostream, but even more so in her self-portraits, she shares intimate emotions for her viewers to take part in the conversation, not only about herself, but also about themselves by a process of catharsis. This responsibility for self-representation is what makes Reber's selfportraits political, they re-enact Hélène Cixous' famous injunction that "a woman must write herself" from The Laugh of the Medusa. ${ }^{36}$ The main difference, when compared to the specifically feminist meaning of Cixous' text, is that Reber's self-representation is more about her humanity than about her femininity.

\section{"Interestingness", Likability and Style: Sarah R. Bloom}

26 A search with the tag "selfie" on Flickr yields more than one and a half million results, and even more, allowing for some overlapping, with the tag "self-portrait". How can we explain such an interest for one's own image? Why do people need a community of (sometimes) strangers to know about their moods and whereabouts? How does, for example, a selfie in front of a Christmas tree add value to a simple photograph of the same Christmas tree? One aspect of the motivation to post selfies is the "buzz" of the competition inherent in posting online: the point, for some users, is to attract as many views, comments and faves (short for favourites), as possible, a goal highlighted in the article "Competitive Photography and the Presentation of the Self," by Alise Tifentale and Lev Manovich, in which, the authors make a difference between two types of photography. One type of photography is the personal, that is to say snapshots whose target audience is mainly the user's family and friends. The authors describe this type of photography as "formulaic and repetitive" ${ }^{37}$ : the users document their lives and do not try to attract a larger audience. The other type of photography is the competitive 
type, "a highly skilled and highly aesthetic practice" in which photographers pay attention to their framing, composition, colour schemes, etc., and whose origins can be traced back to international exhibitions of photography organized by the Fédération Internationale d'Art Photographique (1946). In the same way, I sort the self-portrait and selfies into two categories: the personal, that is to say souvenir and family photos (even though there are also very interesting analyses to be made about this branch of photography) and those that demonstrate more care in their realization.

For this latter category, Flickr has an "Explore" feature favouring a more aesthetic approach, a page where you can admire the 500 most interesting photographs of the day according to a secret algorithm that measures views, comments ${ }^{38}$ and likes, among other things, that the website will not reveal. Flickrites have nicknamed this selection "interestingness." This selection is carefully controlled and is mainly composed of landscapes and animal photography, few portraits and even fewer self-portraits, no nudes, as it has to be SFW (Safe For Work). For a photographer, the result of being "explored" is the thousands of additional views it offers. If that is what a photographer is looking for, the visibility provided by featuring on the Explore page can be an incentive to work on their "likability." ${ }_{39}$

One of the ways to increase one's likability is to develop a personal style, a coherent and recognizable visual identity, as Sarah R. Bloom progressively did. Bloom is based near Philadelphia and has been active on Flickr since 2005. Since 2007, she has been a repetitive participant in the 365 days challenge. Her first year ${ }^{40}$ can be qualified as a typical 365days project: her self-portraits create a diary of her musings, activities and encounters of the year. The style is varied: from snapshots of her face to carefully edited nudes. There is a stylistic evolution in her second year, in her own words, "a year to push myself further" ${ }^{\prime 1}$ : the editing is more elaborate, there are more black and white photographs emulating analogue photography. It is really in her 2010 daily selfportraits that she develops her very personal style, even though it is reminiscent, in a grittier, less surrealist way, of Francesca Woodman's work. Bloom mainly poses nude in rundown buildings, the editing is high in contrast, enhancing the decay both of Bloom's ageing body and of her surroundings. There is also a lot of writing (on which I will elaborate later): titles, captions, and of course the conversations taking place in the comments. One in particular, in which she articulates the politics of her work in a spirited dialogue, deserves to be quoted at length. It follows a photograph of her leaning forward, nude, over a large basin in what seems to be a dilapidated factory.

jim fotia: nice rack

Sarah R. Bloom: Thanks so much. That was the most thoughtful, inspired comment I've ever received. You are clearly an extremely intelligent human being.

jim fotia: Oh, I'm sorry did I miss something?

Sarah R. Bloom: OK, I'll stop the sarcasm and try to actually discuss this by giving you the benefit of the doubt that you'll hear where I'm coming from.

I pose nude for a reason in these self-portraits. I realize to some it may seem gratuitous, but for me there are many layers of meaning to it. There is keeping the whole image figurative; there is removing any context of fashion in time; there is me showing frailty and vulnerability, as well as strength and sometimes defiance. Currently I am interested in expressing and exploring how it feels to be a 41 year old American woman whose body is aging and who is still a victim to society's standards and influence. The decay of the abandoned buildings; the dirt and the grime and the machinery in some; the remnants of former lives; the ghosts of the past...these create an environment that helps to illustrate my inner struggles.

When guys come along and say 'nice rack' it sort of cheapens the whole thing and 
all the work I put into my images. It feels demeaning and while it may inherently be a compliment, it feels insulting. I already had a much more graphic comment earlier today that I simply deleted and blocked the guy, so I will admit I may be a bit more sensitive to yours than I might have been otherwise.

So that's where I'm coming from. If all you see when you look at this image is "nice rack", then yeah, you're missing something. [...]

jim fotia: Ok, thanks . I do apologize for my comments, the first was rude, the second was sarcasm, but at first glance my initial thought was wow, nice rack. I guess your pics really do stir up many different emotions. Again I do apologize for my comment.

Sarah R. Bloom: Thank you for your apology, and for hearing me. I very much appreciate it. I do usually have some sense of humor about this stuff, by the way! $:-)^{42}$

The dialogue opens with "nice rack", a vulgar comment expressing a lewd and dehumanizing appreciation of the artist's bare breasts, as if this image was nothing more than a "gratuitous", that is to say exhibitionist, photograph. This triggers a sarcastic response from Bloom. This could have been the end of the exchange, but the Flickr user expresses a modicum of interest that gives Bloom the opportunity to vindicate her work and explain how it displaces the usual politics of representation. For her, the Internet is a place of desinvisibilization of her ageing body, all the more important for her that she uses her naked body to better stage her vulnerability. Here, the space of expression provided by the comments section contributes greatly to the articulation of the work's politics.

For Bloom, but also for Bernoff or Reber, the self-portrait can be a means of empowerment, because they consider that they belong to an under or misrepresented group of American, or more generally Western, society, the older or ageing woman, the gender non-conforming, the depressed and differently abled, and they use the selfie and the digital self-portrait online to carry out their process of desinvisibilization, or to represent themselves in their own terms, to write their own narratives, because digressive bodies represented by others would a form of violence. We, as viewers, witness the photographer build their identity as a person and their visual identity as a photographer at the same time, and this process is infrapolitical, potentially unnoticeable as a political act but nevertheless contributing to a society's political discourse. However discreet, the political claims made by the photographers to be seen as they actually are and feel, remain archived online, for the world to see, possibly forever.

\section{Selfies in Museums: Me as Art}

31 In the 1880s, thanks to the technological advances of the Eastman Kodak brand, photography started becoming accessible to the larger population, albeit still a narrow class of mainly Western Europeans and North Americans who had the means and leisure time to have such a hobby. Democratization meant that more people could be represented, more diversity could be shown. However, the process of photography was also considerably quickened and thus suspected of increasing thoughtlessness and artlessness, ${ }^{43}$ as the famous Kodak ad claimed, "You press the button and we do the rest." This advertising campaign marked a turning point in the history of photography. As it gained strength as an industry and a social practice, its artistic and technical 
aspects were consequently weakened: it was becoming too quick and popular, good to capture time or memories but too banal to bear a worthy political message.

More than a century later, the pairing of photography in general-and smartphone selfies in particular-with lack of both artistic value and political importance, persists. However, some photographers' creativity succeeds in turning the mechanical act of taking a photograph into a creative production. Indeed, even though they are spontaneous and shared for free on social networks, some selfies or series of selfies are actual works of art and are on their way to becoming part of the art institution. For example, some galleries have used the trend as a theme for exhibitions, like London's Saatchi Gallery "From Selfie to Self-Expression" in 2017. Other forms of vernacular works, such as commercial photography or personal snapshots, have also been appropriated by some museums or institutions in the 2000s, to renew the viewers' interest and curiosity in their collections by offering a vision of intimacy and everyday life as seen by amateurs or commercial, high-street photographers, like the exhibition "In the Vernacular" at the Arts Institute of Chicago in 2010. Similarly, some selfies have started finding their way into museums ${ }^{44}$ as shown for example by the event National \#Selfie Gallery at the Moving Image contemporary art fair in 2013, or the exhibition Performing for the Camera at the Tate Modern in 2016. However, selfies displayed in museums can be considered as a form of cultural appropriation, the taking over by the institution of artefacts whose prime purpose is to circulate online in order to spark conversations there, rather than being blown up and ossified, so to speak, on the walls of a gallery or museum.

Arguably, a livelier approach is that of the selfie taken in a museum, the \#artselfie or \#museumselfie, that contributes to the construction of the selfist's personality by contact with the works of art. The potential devaluation of works of art due to selfietaking is of lesser importance than the question of how the performance of the self is renewed when the photographer stages him or herself with a piece of art. According to psychologists Robert Kozinets, Ulrike Gretzel and Anja Dinhopl, selfies and selfportraits taken in a museum "are a gesture of ownership, a way of owning the art through its images. Selfies allow individuals to weave museum objects into their own identity." ${ }^{45}$ The association of the self with art which is legitimized by the museum institution is another way of empowering one's self-representation.

The ways of intertwining one's persona with adjoining artwork are plenty, beyond the art-as-wallpaper approach. In the case of projected images or dramatic mirroring surfaces, selfists can immerse themselves within the art, thus effectively heightening the sensory experience of the art. An example of this performance of the self is Flickr user Mr JM Burt, who uses a panoramic view of himself ${ }^{46}$ to wish his audience a happy new year within Yayoi Kusama's infinity mirror room entitled "Aftermath of Obliteration of Eternity" (2009). This means that he wants to signal his presence inside a piece of art as a symbolic image for his year as a whole. That way, he simultaneously takes part in the selfie trend that posing within a Kusama artwork has become ${ }^{47}$ and creates an analogy between his life that year and an artistic performance.

In the trend of the goofy artselfie, the photographer wants to interact with the work of art in a funny or witty way, by making a face at it or copying the model's pose, or controversially pretending to touch the canvas or the sculpture. Here again, the purpose is to express one's individuality, and the personal and humorous relationship that the photographer has with a particular work of art will serve as a metaphor for the 
photographer's performance of the self. Flickr and Instagram user, Faux-Teak is a regular museumselfie shooter, and uses for example Robert Mapplethorpe's iconic portrait of Lisa Lyon in a veiled hat flexing her biceps to give a feminist message of female empowerment under the hashtag \#ladiesmakingfists. ${ }^{48}$

Finally, some people also photograph themselves in the museum without any works of art present, another way of trying to establish the personality of the photographer as worthy of interest, "as if to state, more clearly than in any other selfie case: 'I am in the museum, therefore I am the art." ${ }^{49}$ This in itself is a political gesture to re-establish oneself as a valuable subject, in the face of a Western, capitalist society that might seem to crush individuals, valued mainly for their ability to work and not their creativity, especially when their "art" can be consumed for free online. Even if this gesture might seem trivial, its political relevance is undeniable: by contiguity to the art work or the art world, the photographer can acquire a worth and an "interestingness" that can be personally empowering.

\section{Self-Portraits and the Politics of Hybrid Writing}

The interdependency of selfies and language appears in the number of neologisms and portmanteau words, sometimes playfully ambiguous, which were created to define its different trends. A helfie, a selfie with a spectacular hairstyle, can also be a halfie, if only half of your face is in the photograph. A belfie can figure prominently your buttocks, but can also have been shot in Belfast. A felfie was invented in 2014 when the Irish Farmer Journal launched a farmer selfie contest to expose farmers' isolation. A shelfie is when photographers pose in front of a bookshelf to emphasize their culture. A smize is when you smile only with your eyes. The list goes on. The proliferation of such labels demonstrate that the selfie is never only an image, but always works in conjunction with paratextual elements: titles, captions, hashtags, geolocation, as well as the public's comments and reactions. Indeed, my contention is that a selfie is not a selfie if it is not placed at the centre of a dialogue that can become a conversation between its author and whoever has a comment to make about it. Such texts create an impression of either worthless digital chatter, for critics who promulgate the moral panic about selfies as a pathological pursuit responsible for individualism, anorexia, and other mental health issues,,$^{50}$ or a renewed genre of autobiography that mixes image and text, and can be either personal or collaborative, or both. The image is thus made more expressive by the conversations it is able to generate..$^{51}$ That is why, to come back to one of my first points, a self-portrait shot with a digital camera and shared online places itself in the selfie economy: the sharing counts more than the device. Besides, to trigger the viewer's comments and reactions, the paratextual elements count just as much as the visual elements. For example, in an arm's length self-portrait entitled "The Carving," 52 Flickr user Brigid Pierce (SaylaMarz) creates suspense to enhance the interest for the picture. First, she says she has cut two-thirds of her hair and that is the "before" picture in a putative "before" and "after" diptych. Her contacts then react, expressing their surprise and demanding the "after" selfie, playfully contributing to the conversation of the selfie. This manipulation of the viewer's response is characteristic of the genre.

Bernoff, Reber and Bloom, the three photographers I have followed throughout this article, describe themselves, in one way or another, as writers. In an earlier Flickr 
biography, now edited, Ray Bernoff described himself as an avid blogger, and he still presents himself as an unprofessional writer in his Twitter biography. ${ }^{53}$ His blog presents short texts about his everyday life and the circumstances of his photo shoots, but he stays relatively discreet about his transition, the photographs being selfexplanatory.

Nicole Reber writes of herself, "I'm terrible with words, so I use pictures instead." 54 Terrible with words as she might be, all her self-portraits have titles, captions and tags, albeit often quotes from the songs and novels she loves. Even if they are quotations and not personal texts, her paratextual elements contribute to her infrapolitical message. She wants to represent herself in all her complexities: a young gay woman with anxiety, chronic pain and suicidal tendencies. This is perfectly encapsulated in an image in which she appears in a nude self-portrait huddled in her shower next to a spilled vial of pills..$^{55}$ The title, "This is where I say I've had enough," insists on her wish to die. Her caption, which continues the quote from the Dashboard Confessional's song "Saints and Sailors", is ambiguously about her physical or mental health: "And no one should ever feel the pain that I feel now./ A walking open wound,/ A trophy display of bruises/ And I don't believe that I'm getting any better." The tags displace the politics of the piece from mental health to censorship and representation of the naked female body: "I wanted to edit out my nipple [...] now I have to mark it moderate. Dammit. You don't see people flagging dog nipples or male nipples. What's the big deal anyway." So we see that there is a multi-layered narration, the photograph as an illustration to the mental health issues expressed in the title, the caption reminding that the mental and physical health issues are intertwined, but the tags creating a sort of subplot in which concerns about photography and self-representation prevail, the life force counteracting the death force of the pills. In the tags, we eventually learn that the pills that are visually associated with suicide are actually pain relief pills.

Sarah R. Bloom is the most articulate photographer of the three main photographers of the present corpus. I have already described how she makes the most of her comments section to emphasize the politics of her work. Since 2015 she has also inserted texts into her daily self-portraits. ${ }^{56}$ Intimate at first-the overlay of her self-portrait with a handwritten page of her diary-the interplay of self-portrait and writing becomes more political in her seventh year of self-portraiture: "My theme for the year? A Feminist Manifesto, of sorts. A call and response. There will be positive sayings about women and negative sayings. Some will be quotes. Some will be one word insults." ${ }^{57}$ The year is supposed to be seen in its entirety, but as an example of how the series works, her day $336^{58}$ shows her comfortably resting in her bed, looking at the viewer with a gaze that is paradoxically both relaxed and defiant. Overlaid on the black and white photograph is a quote from poet and philosopher Audre Lorde: "Caring for myself is not selfindulgence, it is self-preservation, and that is an act of political warfare." This mirrors the ethos of the politics I want to highlight in this text, when representing oneself is not self-indulgence or self-obsession, it is writing one's personal narrative in one's own terms, and this also is an act of political warfare.

Interestingly, these politics of intimacy open up, in Bloom's case, on the more conventional meaning of the word politics, as in party politics and the leadership of her country. In the wake of the assassination of George Floyd by four policemen filmed on a smartphone by a teenager, the outrage felt by a large proportion of American society is noticeable in her photostream, and most of her self-portraits develop the themes of the 
Black Lives Matter movement and of white privilege. The latest to date, not yet uploaded to Flickr but already visible on Facebook, is ironically captioned: "Entitled suburban girl/I expected the world/to be easy/what a shock to discover/it has been." 59 The purpose of the caption is here to enhance the political meaning of the work, either by actually explaining it, or by alluding to it through irony or sarcasm. Those textual elements are what contribute to transcending a non-political image into an infrapolitical one, by creating a verbal discourse that parallels and amplifies the visual discourse.

\section{Conclusion: Selfies, Digital Self-Portraits, and the Politics of the Mundane}

It is an oversimplification to define each selfie as narcissistic. A selfie is first a way to carve a place for oneself in a world that renders the individual increasingly anonymous. A selfie can have a soothing effect, maybe because for some it has a ritual dimension: there are daily or weekly selfies, haircut selfies, party selfies etc. The selfie transforms the selfist's life into a constellation of minute performances. The mundane (non)events represented in the selfie become self-defining moments that will remain not only as long as they are remembered but as long as they are archived online. Selfies are political when they redefine the "ethics of looking" 60 by refusing both the violence of representation by others, and the violence of erasure from representation. These photographs acquire their infrapolitical value from their liminal position: they are both intimate and public. Away from mainstream media and made by amateurs, ${ }^{61}$ they are invisible except for those actively looking for them through tags or in thematic groups. Internet users, although aware of the little worth of their selfies and self-portraits, nevertheless upload them tirelessly. This creates a corpus of online self-portraits and of selfies which, like any work of art posted exclusively on the Internet, is challenging to analyse, because it is in constant evolution, dynamically constructing itself under our eyes, a characteristic of our hypermodern, connected society. This shifts the focus of study, from the created object to the very process of creation. Indeed, the value of the selfie, or of the daily or frequent self-portrait taken to be uploaded on the Internet, could also come from the equally mundane and simple way it treats human experience, making each occurrence an epiphany with which the viewer might identify. Changing sex, suffering from anxiety, fooling around in front of your bathroom mirror, being involved in your country's politics are treated equally, creating a pool of relatable human experiences, an infinity of first-person narratives that, cumulatively, politicize their author's intimacy.

\section{BIBLIOGRAPHY}

Ackel, Julia, Jens Ruchatz and Sabine Wirth. Exploring the Selfie, Historical, Theoretical and Analytical Approaches to Digital Self-Photography. London: Palgrave Macmillan, 2018. 
Agger, Ben. Oversharing: Presentations of Self in the Internet Age. New York: Routledge, 2012.

Arendt, Hannah. The Human Condition. 1958; Chicago and London: University of Chicago Press, 1998.

Baqué, Dominique. Pour un Nouvel art politique. De l'art contemporain au documentaire. Paris: Éditions Flammarion Champs Arts, 2006.

Burns, Anne. "People who take selfies are "..."," www.thecarceralnet.wordpress.com. Accessed July 8, 2020. https://thecarceralnet.wordpress.com/2014/02/11/people-who-take-selfies-are/ \#_edn1

Brunet, François. La Naissance de l'idée de photographie. Paris: PUF, 2012.

DIS Collective. \#artselfie. Paris: Jean Boîte Éditions, 2014.

Foucault, Michel. Discipline and Punish. Translated by Alan Sheridan. New York: Pantheon, 1977.

Freund, Gisèle. Photographie et Société. Paris: Éditions du Seuil, 1974.

Frosh, Paul. "The Gestural Image: The Selfie, Photography Theory, and Kinesthetic Sociability," International Journal of Communication, (September 2015): 1607-1628.

Gunthert, André. "L'image conversationnelle, Les nouveaux usages de la photographie numérique.” Études Photographiques 31, (Spring 2014): 54-71.

Jurgenson, Nathan. “The Faux-Vintage Photo.” The Society Pages, Cyborgology, May 14, 2011. Accessed October 15, 2020. https://thesocietypages.org/cyborgology/2011/05/14/the-fauxvintage-photo-full-essay-parts-i-ii-and-iii/

Kozinets, Robert, Ulrike Gretzel and Anja Dinhopl. "Self in Art/Self As Art: Museum Selfies As Identity Work." Frontiers in Psychology 8, 2017.

Kunstman, Adi, ed. Selfie Citizenship. London: Palgrave Macmillan, 2017.

Lebovici, Elizabeth. L'Intime. Paris: ENSBA, 1998-2004.

Lichtensztejn, Agathe. Le Selfie, aux frontières de l'égoportrait. Paris: L'Harmattan, 2015.

Manovich, Lev. "Selfiecity Investigating the style of self-portraits (selfies) in five cities across the world," accessed July 06, 2020. http://selfiecity.net/

Marche, Guillaume. La Militance LGBT aux États-Unis : sexualité et subjectivité. Lyon: Presses Universitaires de Lyon, 2017.

Mirzoeff, Nicholas. How to See the World. Harmondsworth: Penguin Random House, Pelican Books, 2015.

--_. An Introduction to Visual Culture. New York: Routledge, 1999, 2009.

Naivin, Bertrand. Selfie, Un nouveau regard photographique. Paris: L'Harmattan, 2016.

-_-, (ed). Selfie(s). Analyses d'une pratique plurielle. Paris: Hermann, 2018.

Saltz, Jerry. “Art at Arm's Length.” In Ego Update: A History of the Selfie, edited by Alain Bieber, 30-49. London: Koenig Books, 2016.

Scott, James C. Domination and the Arts of Resistance: Hidden Transcripts. New Haven and London: Yale University Press, 1990.

Sontag, Susan. On Photography. Harmondsworth: Penguin, 1977. 
Spivak, Gayatri C. "Can the Subaltern Speak?" In Marxism and the Interpretation of Culture, edited by Cary Nelson and Lawrence Grossberg, 271-313. Chicago: University of Illinois Press, 1988.

Hito Steyerl, "In Defense of the Poor Image," e-flux journal, 10, November 2009. http://www.eflux.com/journal/10/61362/in-defense-of-the-poor-image/ <accessed on October 15, 2020>

Tifentale, Alise. “The Selfie: More and Less than a Self-Portrait.” In The Routledge Companion to Photography and Visual Culture, edited by Moritz Neumüller, 44-58. London, New York: Routledge, 2018.

Vander Gucht, Daniel. L'Expérience Politique de l'Art, Retour sur la définition de l'art engagé. Bruxelles: Les Impressions Nouvelles, 2014.

Varga-Dobai, Kinga. "Remixing Selfies: Arts-Based Explorations of Funds of Knowledge, MeaningMaking, and Intercultural Learning in Literacy." International Journal of Multicultural Education 20,

2, (2018): 117-32.

Wendt, Brooke. The Allure of the Selfie. Instagram and the New Self-Portrait. Amsterdam: Network Notebooks series \#8. Amsterdam: Institute of Network Cultures, 2014.

\section{NOTES}

1. That was in France in the nineties. The name of the brand, unfortunately, eludes me.

2. Gisèle Freund, Photographie et Société (Paris: Éditions du Seuil, 1974), 11.

3. Nicholas Mirzoeff, How to See the World (Great Britain: Penguin Books, A Pelican Introduction, 2015), 62. This was also noticed by André Gunthert in "L'Image Conversationnelle, les nouveaux usages de la photographie," Paris: Études Photographiques, Société Française de Photographie, n 31, (Spring 2014), although Gunthert makes this point for any networked image and not only selfies and self-portraits.

4. Ben Agger, Oversharing: Presentations of Self in the Internet Age (New York: Routledge, 2012).

5. See also Beatrice Trotignon's "Portrait of a Selfie" in this volume.

6. Nathan Jurgenson, "The Faux-Vintage Photo," Cyborgology, The Society Pages, May 14, 2011. https://thesocietypages.org/cyborgology/2011/05/14/the-faux-vintage-photo-full-essay-parts-iii-and-iii/ <accessed on October 15, 2020>. For a more theoretical analysis of filters and algorithms in our culture, see also Rettberg J.W., "Filtered Reality" in Seeing Ourselves Through Technology: How We Use Selfies, Blogs and Wearable Devices to See and Shape Ourselves, (London: Palgrave Macmillan, 2016).

7. Hito Steyerl, "In Defense of the Poor Image," e-flux journal, 10, November 2009. http://www.eflux.com/journal/10/61362/in-defense-of-the-poor-image/ <accessed on October 15, 2020>

8. James C. Scott, Domination and the Arts of Resistance: Hidden Transcripts (New Haven and London: Yale University Press, 1990).

9. Guillaume Marche, "Why Infrapolitics Matter," Revue française d'études américaines, 2012/1 $\mathrm{n}^{\circ} 131,3$.

10. Daniel Rubinstein and Katrina Sluis, "A Life More Photographic; Mapping the Networked Images," Photographies, March 1, 2008, 9-28.

11. Camera breakdown on the Flickr.com photographic platform. https://www.flickr.com/ cameras/ <accessed on July 06, 2020>.

12. Lev Manovich, "Selfiecity Investigating the style of self-portraits (selfies) in five cities across the world," http://selfiecity.net/ <accessed on July 06, 2020>

13. 365days pool on Flickr.com. https://www.flickr.com/groups/365days/pool/with/ 50014235413 / <accessed on July 06, 2020>. 
14. Daniel Vander Gucht, L'Expérience Politique de l'Art, Retour sur la définition de l'art engagé (Bruxelles: Les Impressions Nouvelles, 2014), 11.

15. Nicholas Mirzoeff, An Introduction to Visual Culture (London and New York: Routledge, 1999-2009), 96. See also Michel Foucault, Discipline and Punish, the Birth of the Prison (1977; New York: Random House, 1995).

16. Paul Frosh, "The Gestural Image: The Selfie, Photography Theory, and Kinesthetic Sociability," International Journal of Communication, (September 2015): 1607-1628.

17. Anne Burns, "People who take selfies are “..."," www.thecarceralnet.wordpress.com. https:// thecarceralnet.wordpress.com/2014/02/11/people-who-take-selfies-are/\#_edn1 <accessed on July 8, 2020>

18. Bertrand Naivin, Selfie: un Nouveau Regard Photographique (Paris: L'Harmattan, Collection Eidos, Série Photographies, 2016), 136.

19. MacMyMillerPlease, Lizzie. 2012. “Ghetto Mirror Selfie?” Flickr.com, December 29, 2012. https://www.flickr.com/photos/mac_my_miller_please/8324392786/ <accessed on July 7, 2020> 20. Hito Steyerl, "In Defense of the Poor Image"

21. Bernoff, Ray. 2011. "I don't know when I suddenly turned into an emo myspace bitch, but here. Have the results of that." Flickr.com, November 29, 2011. https://www.flickr.com/photos/ 67350247@N02/6428865235/in/album-72157627912255177/ <accessed on February 07, 2020> 22. Bernoff, Ray. 2017. “2017-08-21 Prop Cigarette Lighting Test 016.” Flickr.com, August 21, 2017. https://www.flickr.com/photos/67350247@N02/24010451258/in/album-72157627912255177/ $<$ accessed on March 17, 2019>

23. Bernoff, Ray. 2015. "glitter." Flickr.com, January 28, 2015. https://www.flickr.com/photos/ 67350247@N02/16392173342/in/album-72157627912255177/ <accessed on March 17, 2019>

24. Elizabeth Lebovici, L'Intime (Paris: ENSBA, 1998-2004), 12.

25. Carol Hanisch, "The Personal is Political," http://www.carolhanisch.org/CHwritings/ PersonalIsPol.pdf <accessed on October 10, 2020>.

26. James C. Scott, Domination and the Arts of Resistance: Hidden Transcripts (New Haven and London: Yale University Press, 1990), quoted in Guillaume Marche, La Militance LGBT aux États-Unis: sexualité et subjectivité (Lyon: Presses Universitaires de Lyon, 2017), 141.

27. Human Rights Campaign. https://www.hrc.org/blog/hrc-mourns-tony-mcdade-blacktransgender-man-killed-in-florida/ <accessed on July 06, 2020>.

28. Also noted in Chiara Salari's article, "Postcards from Google Earth," in the present issue.

29. Jonathan Pearlman, "Australian man 'invented the selfie after drunken night out'," The Telegraph, November 19, 2013. https://www.telegraph.co.uk/news/worldnews/ australiaandthepacific/australia/10459115/Australian-man-invented-the-selfie-after-drunkennight-

out.html\#: :text=The\%20Australian\%20who\%20is\%20the,about\%20stitches\%20in\%20his\%20lips $<$ accessed on July 06, 2020>

30. I am using some of the ideas of the cycle of lectures organized by Bertrand Naivin, “Selfies(s)?" November 4th, 2016, University of Paris VIII-Vincennes. See also his edited volume, Selfie(s). Analyses d'une pratique plurielle (Paris: Hermann, 2018).

31. Reber, Nicole. "Emotions.” Flickr.com. https://www.flickr.com/photos/like_shipwrecks/ albums/72157605241840343 <accessed on July 06, 2020>

32. Reber, Nicole. "Tag breakdown," Flickr.com. https://www.flickr.com/photos/ like_shipwrecks/tags\#S-tags/ <accessed on July 06, 2020>

33. Reber, Nicole. 2007. "Day 33 - Do you ever feel like crying?" Flickr.com, January 3, 2007. https://www.flickr.com/photos/like_shipwrecks/2322397343/in/album-72157605241840343/ $<$ accessed on July 06, 2020>

34. Hannah Arendt, Condition de l'Homme moderne (1961; Paris: Calmann-Lévy, 1983). 
35. My translation. Baqué writes "L’art en deçà du politique”. Dominique Baqué, Pour un Nouvel art politique, De l'art contemporain au documentaire, (Paris: Champs Art, Flammarion, 2004 and 2006), 35.

36. Hélène Cixous, “The Laugh of Medusa”, Signs, Vol. 1, Nº4 Summer 1976, 875-893.

37. Alise Tifentale and Lev Manovich, "Competitive Photography and the Presentation of the self," in Exploring the Selfie, Historical, Theoretical and Analytical Approaches to Digital SelfPhotography, ed. Julia Ackel, Jens Ruchatz, and Sabine Wirth (London: Palgrave Macmillan, 2018), 174.

38. The measurement of the artistic value or narrative interest of a document, in her case a scene from a TV series, is one of the themes broached by Ariane Hudelet in the present volume.

39. Alise Tifentale and Lev Manovich, "Competitive Photography and the Presentation of the self"

40. Bloom, R., Sarah. 2006. “365 Days.” Flickr.com, https://www.flickr.com/photos/ sadandbeautiful/albums/72157594242354644/ <accessed on July 06, 2020>

41. Bloom, R., Sarah. 2007. “365 Year Two." Flickr.com, https://www.flickr.com/photos/ sadandbeautiful/albums/72157601564854400/page1 <accessed on July 06, 2020>

42. Bloom, R., Sarah. 2010. "So melts the youth, and languishes away." Flickr.com, November 15, 2010. https://www.flickr.com/photos/sadandbeautiful/5208535027/in/ album-72157623188206949/<accessed on July 06, 2020>

43. François Brunet, La Naissance de l'idée de photographie (Paris: PUF, 2012), 217.

44. See Martine Beugnet's article on the evolution of museum spaces.

45. Robert Kozinets, Ulrike Gretzel, and Anja Dinhopl, "Self in Art/Self As Art: Museum Selfies as Identity Work," Frontiers in Psychology, 8.7311, 1 (March 2008): 9-28 4.

46. Mr JM Blunt. 2018. "Happy new year.” Flickr.com, January 1, 2018. https://www.flickr.com/ photos/146918744@N08/38553510775/in/dateposted/ <accessed on July 06, 2020>

47. Janelle Zara, "Yayoi Kusama's Infinity Mirrors reignite art's selfie debate”, The Guardian, November 11, 2017.

48. Faux Teak. 2019. “\#Ladiesmakingfists.” Flickr.com, March 15, 2019. https://www.flickr.com/ photos/15127734@N04/32440972337/in/dateposted/ <accessed July 06, 2020>

49. Kozinets, Gretzel, and Dinhopl, "Self in Art/Self As Art [...],"

50. M. I. Adamkol, H. Elmi-Nur, "Communicating 'the self' through digital images: gender bias and mental health risks associated with selfie use on social network sites," Glob. Media J. Malays, 2015, Ed. 5, 16-36.

51. In the same way as the amount of commentary and buzz about a scene in a series determines its status as a "moment" worthy of academic interest, in the process of "collective choosing," see Ariane Hudelet, "The Problem of Long Duration."

52. Maybe later reappraised by the artist as too anecdotic, this photograph was subsequently deleted from the website. The disappearance of online content is always possible and is one of the peculiarities of my research.

53. Bernoff, Ray (@rmhbernoff). https://twitter.com/rmhbernoff?lang=en/ <accessed on July 06, 2020>.

54. Reber, Nicole. “About.” Flickr.com. https://www.flickr.com/people/like_shipwrecks/ $<$ accessed on July 06, 2020>.

55. Reber, Nicole. 2009. "Day 5 - This is where I say I've had enough.” Flickr.com, January 5, 2009. https://www.flickr.com/photos/like_shipwrecks/3172120563/in/album-72157613708585548/ $<$ accessed July 06, 2020>

56. Bloom, R., Sarah. 2015. "Number 6: 365 Daily Self-Portraits." Flickr.com. https:// www.flickr.com/photos/sadandbeautiful/albums/72157650064292075/ <accessed on July 06, 2020> 
57. Bloom, R., Sarah. 2016. "Lucky Number 7: Daily Self-Portrait Project." Flickr.com. https:// www.flickr.com/photos/sadandbeautiful/albums/72157660717054424/ <accessed on July 06, 2020>

58. Bloom, R., Sarah. 2016. “336.366.” December 1, 2016. https://www.flickr.com/photos/ sadandbeautiful/31313221892/in/album-72157660717054424/ <accessed on July 06, 2020>

59. Bloom, R., Sarah. 2020. “171.366.2020.” Facebook, June 20, 2020. https://www.facebook.com/ photo?fbid=10157211129596475\&set=a.1015676881957647/ <accessed on July 06, 2020>

60. J.B. Brager, "On the Ethics of Looking," in Selfie Citizenship, ed. Adi Kunstman (London: Palgrave Macmillan, 2017), 162.

61. Sarah R. Bloom, for example, defines her daily self-portrait work and abandoned work as being on an amateur level, although working as a photographer commercially (private email conversation).

\section{ABSTRACTS}

This text explores the representation of one's intimate images, namely selfies, and the possibility of their political implications. It focuses on the photo-sharing website Flickr, partly because this platform enables its users to sort their photographs into albums, which in turn allows them to bring their self-portraits to the forefront, if they wish. Empowerment, that is to say taking back control over one's representation, is a sign of the politicization of selfies and digital selfportraits. Can selfies be a means of empowerment when, shot in a museum, the image itself posits that the photographer's very being is a work of art? Can they change our relationship to writing by encouraging neologisms and by creating the conditions for the writing of first-person, hybrid narratives mixing text and photography? The paradox of the politicization of selfies is that photographers use the lever of their intimacy to convey political messages. This can take the form of depicting a gender-reassignment process, or health issues, for example. At the origin of the articulation of a photographer's politicization of their intimacy is a need for validation of the intimate self through audience response. On the audience's side, each intimate self-portrait gives the possibility of a cathartic identification between photographer and viewer, which breaks the isolation of both protagonists in the relationship. Thus, selfies and self-portraits can re-empower photographers and viewers who consider that they belong to a misrepresented minority. We will question in what measure selfies and self-portraits can be an infrapolitical way of fighting against erasure.

\section{INDEX}

Keywords: selfie, self-portrait, social media, intimacy, politics 


\section{AUTHOR}

\section{JULIETTE MELIA}

Juliette Melia teaches English and English Literature in a high school in the Paris area, as well as at the Université de Paris. She completed her Ph.D. at the Université de Paris on self-portraiture in contemporary British and American photography from the 1970s to the present and is currently working on a book project on the politics of representation in Catherine Opie's photography. 